Int. J. Morphol.,

28(2):515-518, 2010.

\title{
Frequency of Occurence of the Discomalleolar Ligament in the Adult Man
}

\author{
Frecuencia Aparición del Ligamento Discomaleolar en el Hombre Adulto
}

"Nilton Alves \& **Naira Figueiredo Deana

ALVES, N. \& DEANA, N. F. Frequency of occurence of the discomalleolar ligament in the adult man. Int. J. Morphol., 28(2):515-518, 2010.

SUMMARY: The discomaleollar ligament is not described in the anatomy textbooks but was demonstrated by Pinto (1962) and others. It is a ligamentous structure connecting the malleus in the tympanic cavity and the articular disc and the capsule of the temporomandibular joint. This anatomical relationship between the middle ear and temporomandibular joint is supposed to be one of the explanations for the otological symptons associated with temporomandibular joint dysfunction. The aim of our study was to determine the frequency of occurence of the discomaleollar ligament. Twenty hemi-heads of adults human were carefully dissected from a superior approach through the middle cranial fossa. The bone of the middle cranial fossa over the temporomandibular joint region and the roof of the tympanic cavity were carefully removed to expose the articular disc, ossicles of the middle ear, lateral pterygoid muscle and other structures in the region. The discomalleolar ligament was found in all studied cases what allow us to suggest that it is an intrinsic ligament of the temporomandibular joint.

KEY WORDS: Discomalleolar ligament; Temporomandibular joint; Articular disc; Otological symptons.

\section{INTRODUCTION}

The discomalleolar ligament is not mentioned in anatomy textbooks. Although its existence has been demonstrated and several authors have established an anatomic relation between the temporomandibular joint, the middle ear and the Huguier's canal (Coleman, 1970; Ioannides \& Hoogland, 1983; Rodríguez Vázquez et al., 1992; Alkofide et al., 1997; Mérida Velasco et al., 1997) there are other authors that claim it can't always be observed.

Pinto (1962) described a fibroelastic structure inserted in the neck of the malleus, laterally to the chorda tympani nerve. Coleman studied the discomalleolar ligament in human adults and fetuses and described a triangular shaped band of connective tissue, the base of which is continuous with the posteromedial portion of the disc and articular capsule which enters in the middle ear through the petrotympanic fissure; some fibers are connected to the walls and others are continuous with the lateral margin of the anterior ligament of the malleus. According to Toledo Filho et al. (1985), fibers of the middle and lower fascicle of the anterior ligament of the malleus pass through the petrotympanic fissure to insert into the capsule and disc of the temporomandibular joint. Cesarani et al. (1991) observed a thin fibrous connection between the capsule of the temporomandibular joint and the neck of the malleus which they considered corresponded to a portion of the anterior ligament of the malleus.

Rodríguez Vázquez et al. (1993) systematized the relationships between the temporomandibular joint and the middle ear and studied the origin and development of the discomalleolar ligament.

This ligament, which has an embryological remnant of the lateral pterygoid muscle (Pinto), goes through the posterior superior part of the temporomandibular joint disc aiming the malleus of the middle ear and is attached to the neck and base of the anterior process (Rodríguez-Vázquez et al., 1998). 
Alkofide et al. carried out a study in 82 anatomic pieces and noticed that the sphenomandibular ligament could be found near to the malleus in $67.6 \%$ of the samples. The anterior ligament of the malleus was present at the petrotympanic fissure in $64 \%$ of the cases and in $58.3 \%$, it continued on through the fissure, in the sphenomandibular ligament. The anterior ligament of the malleus was found in this bone in all the samples, the same accured with the sphenomandibular ligament, that was found in the petrotympanic fissure in all the samples.

Rodriguez-Vásquez et al. (1998), at a study with 20 adult cadavers, 10 male and 10 female, observed that the discomalleolar ligament was lateral to the sphenomandibular ligament. It prolonged itself above and inside the disc running laterally through the sphenomandibular ligament in direction of the neck and base of the anterior process of the malleus. The discomalleolar ligament is attached slightly to the sphenomandibular ligament outside the middle ear (juxtaarticular portion) and also inside (tympanic portion) and at the margin of the petrotympanic fissure. The discomalleolar ligament overruns the tympanic cavity aiming the lateral portion of the petrotympanic fissure.

The discomalleolar ligament is frequently described in a contradictory way, however, it has proved to be a structure of clinical importance. Some authors describe this structure making a relation with it and the possible cause of auditory symptoms (Ioannides \& Hoogland; Rholin et al., 1985; Loughner et al., 1989; Ögütcen-Toller \& Junniper, 1993). According to some authors, the temporomandibular disorders can cause changes in the ligament structures, including the discomalleolar ligament, that could cause traction in the neck of the malleus and then cause some symptoms such as buzzing and hypoacusis (Pinto; Ioannides \& Hoogland).

Pascoal et al. (2001) examined some patients with a possible temporomandibular disorder and said that $46.8 \%$ of these patients complained about a buzzing feeling. Parker \& Chole (1995) studied the presence of otological symptoms as buzzing sounds and dizziness in patients with a temporomandibular disorder. Regarding the buzzing sounds, there was a significant statistic difference in the group with temporomandibular disorder (59\%), in relation to both groups studied (13.8\% in the group 1 and $32.5 \%$ in the group 2). The buzzing sounds in the patients that had temporomandibular disorder was acute and continuous most of the time, occurring sporadically and for a brief moment, with moderate intensity and did not interfer in the patients' daily activities.

Otological manifestations of buzzing sound and dizziness, as a consequence of temporomandibular disorders has been a controversial subject in literature. Although the real explanation for the relation between auditory symptoms and temporomadibular disorder still remains unclear, the suitable knowledge of the anatomy and physiology of the ear and the temporomandibular joint seems to be crucial to the understanding of the pathologic process that attacks these areas.

The aim of this work is to observe the frequency of the discomalleolar ligament in adult individuals.

\section{MATERIAL AND METHOD}

Twenty hemi-heads (10 right side and 10 left side) from adult individuals of both sexes were used; the heads were mantained in formol $15 \%$. The material was carefully dissected, using a superior approach through the middle cranial fossa. The bone of the middle cranial fossa, found above the temporomandibular joint area and the upper part of the tympanic cavity were carefully removed in order to expose the articular disc of the temporomandibular joint, the auditory ossicles, the lateral pterygoid muscle and other structures of the area.

\section{RESULTS}

In all the cases studied, the malleus and the temporomandibular joint disc were connected by ligaments (Fig. 1). The fibrous structure formed a fine lamina that runs from the temporomandibular joint disc to the middle ear malleus. The discomalleolar ligament started at the tympanic cavity in direction to the lateral portion of the petrotympanic fissure.

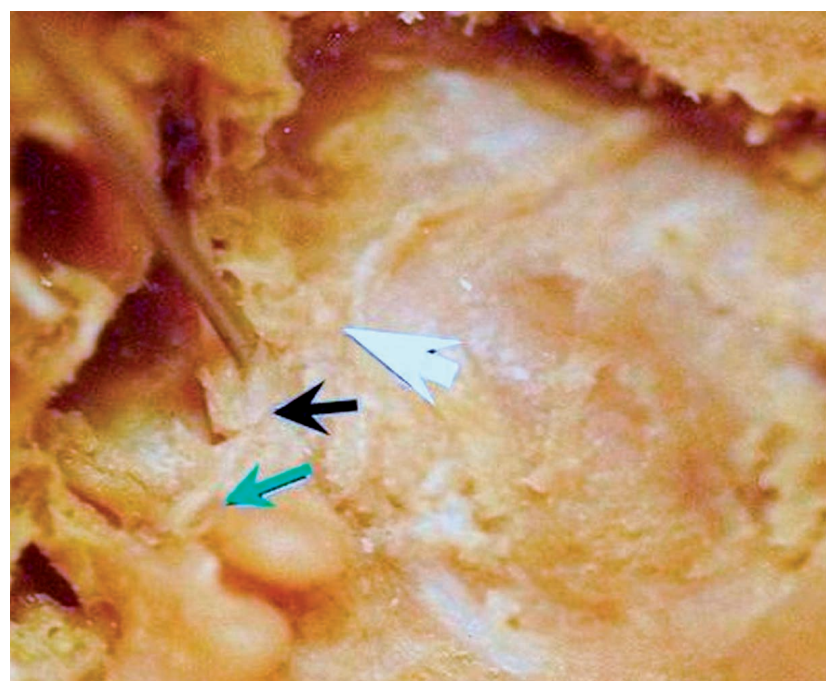

Fig. 1. Upper view of the middle cranial fossa. White arrow: temporomandibular joint disc; green arrow: neck of the malleus; black arrow: discomalleolar ligament. 


\section{DISCUSSION}

The existence of a fine fibrous lamina connecting the ATM disc with the middle ear malleus could be observed in all the studied cases.

We believe that the different denominations that this structure has received contribute to the increased confusion concerning its interpretation.

There are authors that consider this structure as part of the anterior ligament of the malleus (Burch, 1966; Toledo Filho et al.; Cesarani et al.). There are others that claim it is a superior extension of the sphenomandibular ligament at the tympanic cavity (Burch). We do not agree with these authors, as well as with the denomination used by Pinto "a tiny ligament". We agree with Coleman, Komori et al. (1986), Ögütcen-Toller \& Junniper; Rodriguez-Vásquez et al. (1998) and Dai et al. (2007) when they stablish a difference between the discomalleolar ligament and anterior ligament of the malleus. The anterior ligament of the malleus can be considered an extension of the sphenomandibular ligament inside the middle ear. The discomalleolar ligament includes the fibres that extend at the posterior superior portion of the temporomandibular joint capsule to the middle ear.

Some authors have made a relation between certain otological manifestations caused by temporomandibular disorders and this structure (Ioannides \& Hoogland; Rholin et al.; Loughner et al.; Toller \& Junniper). The temporomandibular disorders cover several functional disorders, involving not only the temporomandibular joint as well as the muscles responsible for the mandibular, head and neck movements (Alves \& Cândido, 2009). RodriguezVásquez et al. (1998), believe that the sequencing movement of the ossicles of the middle ear through the discomalleolar ligament traction is possible, depending on the closure degree of the petrotympanic fissure during the development and therefore, the adherence points between the ligament and the petrotympanic fissure margin.

We believe that possible movement of this sequence of bones in the middle ear by traction of the discomalleolar ligament depends on the degree of closure of the petrotympanic fissure during development and, hence, the points of adhesion between the ligament and the edges of the petrotympanic fissure.

Although it was not the aim of this work, we agree with Coleman, Komori et al., Eckerdal (1991), Ricaurte (1991) when they say that there is no evidence that the traction of the discomalleolar ligament can cause repeated movements of the middle ear bones.

We believe that besides being able to provide mechanical energy to the malleus, the discomalleolar ligament can't cause buzzing of great proportions, as the ones described by the patients with temporomandibular disorder. The discomalleolar ligament is firmly attached to the walls of the petrotympanic fissure, not having enough strength to tension the auditory ossicles causing the auditory symptoms.

To conclude, the discomalleolar ligament was found in all the cases studied, which allows us to suggest that it is an intrinsic ligament of the temporomandibular joint.

ALVES, N. \& DEANA, N. F. Frecuencia de aparición del ligamento discomaleolar en el hombre adulto. Int. J. Morphol., 28(2):515-518, 2010.

RESUMEN: El ligamento discomaleolar no se describe en los textos de anatomía, pero ha sido demostrado por Pinto (1962) y otros. Es una estructura ligamentosa que conecta el maléolo en la cavidad timpánica con el disco articular y la cápsula de la articulación temporomandibular. Esta relación anatómica entre el oído medio y la articulación temporomandibular se supone que es una de las explicaciones de los síntomas otológicos asociados a la disfunción temporomandibular. El objetivo de nuestro estudio fue determinar la frecuencia de aparición del ligamento discomaleolar. Veinte hemi-cabezas de individuos adultos fueron cuidadosamente disecadas desde un acceso superior a través de la fosa craneal media. Se retiró el hueso de la fosa craneal media sobre la región de la articulación temporomandibular y el techo de la cavidad timpánica, para exponer el disco articular, osículos del oído medio, músculo pterigoideo lateral y otras estructuras en la región. El ligamento discomaleolar se encontró en todos los casos estudiados, lo que nos permite sugerir que es un ligamento intrínseco de la articulación temporomandibular.

PALABRAS CLAVE: Ligamento discomaleolar; Articulación temporomandibular; Disco articular; Síntomas otológicos. 


\section{REFERENCES}

Alkofide, E. A.; Clark, E.; el-Bermani, W.; Kronman, J. H. \& Mehta, N. The incidence and nature of fibrous continuity between the sphenomandibular ligament and the anterior malleolar ligament of the middle ear. J. Orofac. Pain, 11(1):7-14, 1997.

Alves, N. \& Cândido, P. Anatomía aplicada a la Odontología. 1a Ed. São Paulo, Gen-Santos, 2009.

Burch, J. G. The cranial attachment of the sphenomandibular (tympanomandibular) ligament. Anat. Rec., 156(4):433-7, 1966.

Cesarani, A; Tombolini, A; Fagnani, E. \& Domenech Mateu, J. M. The anterior ligament of the human malleus. Acta Anat., 142:313-6, 1991.

Coleman, R. D. Temporomandibular joint: relation of the retrodiskal zone to Meckel's cartilage and lateral pterygoid muscle. J. Dent. Res., 49:626-30, 1970.

Dai, C.; Cheng, T.; Wood, M. W. \& Gan, R. Z. Fixation and detachment of superior and anterior malleolar ligaments in human middle ear: experiment and modeling. Hear Res., 230(1-2):24-33, 2007.

Eckerdal, O. The petrotympanic fissure: a link connecting the tympanic cavity and the temporomandibular joint. Cranio, 9(1):15-22, 1991.

Ioannides, C. A. \& Hoogland, G. A. The disco-malleolar ligament: a possible cause of subjective hearing loss in patients with temporomandibular joint dysfunction. $J$. Maxillofac. Surg., 11(5):227-31, 1983.

Komori, E; Sugisaki, M; Tanabe, H \& Katoh S. Discomalleolar ligament in the adult human. Cranio, 4(4):299-305, 1986.

Loughner, B. A.; Larkin, L. H. \& Mahan, P. E. Discomalleolar and anterior malleolar ligaments: possible causes of the middle ear damage during temporomandibular joint surgery. Oral Surg. Oral Med. Oral Pathol., 68(1):14-22, 1989.

Mérida Velasco, J. R.; Rodríguez Vázquez, J. F. \& Jiménez Collado, J. Anterior tympanic artery: course, ramification and relationship with the temporomandibular joint. Acta Anat. (Basel), 158(3):222-6, 1997.

Ögütcen-Toller, M. O. \& Juniper, R. P. Audiological evaluation of the aural symptoms in temporomandibular joint dysfunction. J. Craniomaxillofac. Surg., 21(1):2-8, 1993. Parker, W. S. \& Chole, R. A. Tinnitus, vertigo, and temporomandibular disorders. Am. J. Orthod. Dentofacial Orthop., 107(2):153-8, 1995.

Pascoal, M. I. N.; Rapoport, A.; Chagas, J. F. S.; Pascoal, M. B. N.; Costa, C. C. \& Magna, L. A. Prevalência dos sintomas otológicos nadesordem temperomandibular: estudo de 126 casos. Rev. Bras. Otorrinolaringol., 67(5):627-33, 2001.

Pinto, O. F. A new structure related to the temporomandibular joint and middle ear. J. Pros. Dent., 12:95-103, 1962.

Ricaurte, A. C. R. Informe de investiación: disección del ligamento discomalleolar en especímenes adultos, un niño y un feto. Univ. Odontol., 10(19):15-20, 1991.

Rodríguez Vázquez, J. F.; Mérida Velasco, J. R. \& Jiménez Collado, J. Development of the human sphenomandibular ligament. Anat. Rec., 233(3):453-60, 1992.

Rodríguez-Vázquez, J. F.; Mérida-Velasco, J. R.; MéridaVelasco, J. A. \& Jimenez-Collado, J. Anatomical considerations on the discomalleolar ligament. Short Report. J. Anat., 192:617-21, 1998.

Rohlin, M.; Westesson, P. L. \& Eriksson, L. The correlation of temporomandibular joint sounds with joint morphology in fifty-five autopsy specimens. J. Oral Maxillofac. Surg., 43(3):194-200, 1985.

Rodríguez-Vázquez, J. F., Mérida-Velasco, J. R, \& JimenezCollado, J. Relationship between the temporomandibular joint and the middle ear in human fetuses. J. of Dental Research, 72:62-6, 1993.

Toledo Filho, J. L.; Zorzetto, N. L. \& Navarro, J. A. Structures and relationships of the anterior malleus ligament. Anat. Anz., 158(1):13-22, 1985.

Correspondence to:

Nilton Alves

Unidad de Anatomía Normal, Departamento de Ciencias Básicas y Biomédicas

Facultad de Ciencias de la Salud

Oficina 104 Anatomía. Avenida Lircay s/n, Talca

Universidad de Talca

CHILE

Email: niltonnalves@yahoo.com.br

Received: 22-01-2010

Accepted: 11-03-2010 